\title{
How to preserve the First World War military heritage
}

\author{
M.-M. Damien \\ UFR of Geography and Planning, USTL Lille 1, France
}

\begin{abstract}
The First World War belongs to world history. The important 'footprint' left by this war must be protected and valorised. But, this heritage is a special one: it is a human, emotional, national and transnational heritage. But at first, we have been taking or you are taking a geo-referenced inventory of the last visible scar of this Great War before its disappearance and we want to have recourse to such modern technologies such as "lidar" (laser detection and radar). Then, these properties must be included in conservation areas, or a part of them selected, because we cannot protect everything. Then a part of them may be allowed to belong to the Heritage Preservation UNESCO areas or located in their buffer zones. The nominated property had already been included on the tentative list of the French State Party in agreement with the Flemish and Walloon governments at the request of the "Memory Landscapes and Sites of the Great War Association" gathering the fourteen Front departments, their associative local partners and the local communities. Now, France is announcing its intention to file a request with UNESCO to put eighty places on the list of world heritage sites. A vigilant policy must be implemented in this matter. We need to apply a real conservation and environmental policy in order to respect this heritage in recognition of the fact that we have a duty to pass this human, cultural, emotional universal heritage on to future generations intact. The inscription of these properties on the world heritage list is considered as an excellent way to protect these assets for future generations. Keywords: protected area, conservation area, heritage list, inventory, "lidar", checklist, strategy, GECT, tentative list, archaeological survey.
\end{abstract}




\section{Introduction}

Now, the First World War belongs to World history. Its heritage must be preserved and valorised. For this time, the colossal 'footprint' that the First World War left on landscapes and coasts of the Western Front in France and in Belgium, drawing in community research to enhance our local knowledge.

The First World War was a global conflict lasting over four years. The cost, both economically and in terms of human life, were unimaginably vast. Ten million who fought were killed and more than six million civilians died. Millions more were wounded or left psychologically damaged.

Nowadays, cemeteries, necropolis, mausoleums, war memorials, fortifications, training camps, airfields, country houses requisitioned for use as hospitals, ambulances or key government and military meetings, sites where war poets and conscientious objectors testified to the savagery of this war remind us of this conflict. How to preserve this heritage? Why are we proposing this heritage to the World Heritage List? What strategy and master planning will be used? How may legacy protections be efficient? How may the archaeological research be enhanced?

\section{Why this heritage to the UNESCO World Heritage List?}

\subsection{A human, cultural, emotional national and international heritage}

A century later, reminders are all around us. Some, such as war memorials, are familiar. But by far the majority is unrecognized, neglected, derelict, and many are still to be re-discovered. Together they bear historical witnesses to the Western Front. They are a hugely, important physical and emotional link between the past and the present; it is fundamental to keeping memories and human stories alive for future generations.

It is necessary to retain their integrity to propose this heritage to the UNESCO World Heritage List through a hundred sites and landscapes. This project is a transnational aspiration and view. Some places are well known and preserved such as The Somme Battlefields, Verdun, the Linge...but have many others been forgotten?

\subsection{An opportunity for taking an inventory of remains}

For the UNESCO inscription project, an important geo-referenced inventory with an index-car by property has been realized or is being realized in every French department located on the French Occidental Front and financially supported by each General Council. This important inventory [1] for its large part will not be valorised through the modified UNESCO project limited to funeral sites (necropolis, mausoleums and cemeteries, memorials), but it is very important for our World history and our World First War understanding. And it helps us preserve the natural and historical sites and promote the regions as a national and international memory touristic destination. 
The landscapes and sites project would have been better, because the geography is very important for the military operations. But it was impossible to propose this approach it was ejected by the French World Heritage Committee.

For the French German military historian specialists, as General J.C. Laparra, a Metz Academic Member, these geo-located databases (Thesaurus of the French Architecture [2], Architecture Dictionary [3]) make important scientific contributions to the understanding of the different aspects of the fortifications: here the position of the reverse slope blockhouses for instance (fig. 1). It is very important to explain the Metz Fortifications system because we have a better location of the lines and the position. The French maps established after the war indicated different spatial patterns. Sometimes this inventory reveals surprises, such as this small monument considered as a grave because two names were carved in the stone rim, but they were the well-diggers' names (Moince Mill, Moselle). An interesting gravity-fed supply water system was discovered too with its tank blockhouse and its waterworks. These photos (figs 4 and 5) illustrate some other elements in the North department.

\subsection{A relative national protection and an important archaeological heritage to valorise}

Seldom have these properties been protected except for some necropolis, cemeteries, memorials and some blockhouses by the French acts: Act on the Historic Monuments (31 December 1913) strengthened (1 September 2007) and The Act on the inscribed or classified sites (2 May 1930) relative to Nature Monuments and exceptional sites (artistic, historic, scientific, legendary or picturesque) modified last time (21 September 2000). So, by a ministerial order (22 August 2013) Thiepval and Beaumont-Hamel memorials and the surrounding area have been classified as a conservation historic area to preserve the monument and beautify its surroundings.

So, some sites such as the Somme Battlefields have recently been admitted as conservation areas and The Chauffour quarry (Thiescourt Oise, fig. 6) too. But, other current and proposed sites by the DREAL (Regional Department or the Environment and Housing) Picardy included "Le Chemin Des Dames" but it was rejected by the Aisne General Council. That is why we think that the UNESCO project is very important; and the Centenary marks an important turning point for the conservation strategy on the French Western Front.

But, sometimes, in spite of juridical protection sanitary land-fields are being implanted near them like "Zouaves Hill" (Oise) in spite of its national historic monument inscription ( $\mathrm{N}^{\circ}$ 99490, item: Butte des Zouaves, Battlefiield: cadastral survey: A 31; 2 April 2002) and elsewhere others very important projects exist (Loges Wood in Somme...).Sometimes it is an open-quarry extension that is threatening sites such as Bouxières-sous-Froidmont (Figure 1, 65) and its remains: the dedicated horseman Pouget [4], the first soldier killed after the beginning of the war and its fortifications in Lorraine (Figs 1, 3 and 4). However, these various places will be the subject of international heritage investigations for instance by 


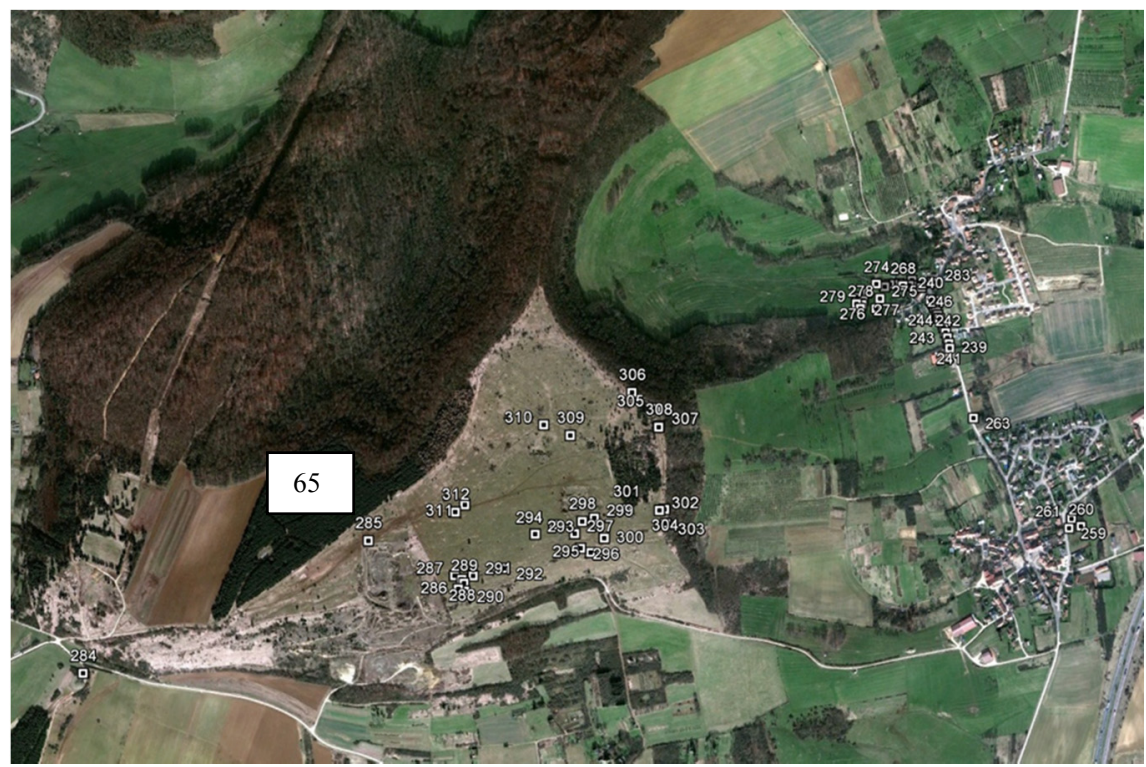

Figure 1: Inventory Bouxières-sous-Froidmont/Vitonville example. Source: Geoportail fond de carte; realisation and database (location blockhouses: M-M Damien).

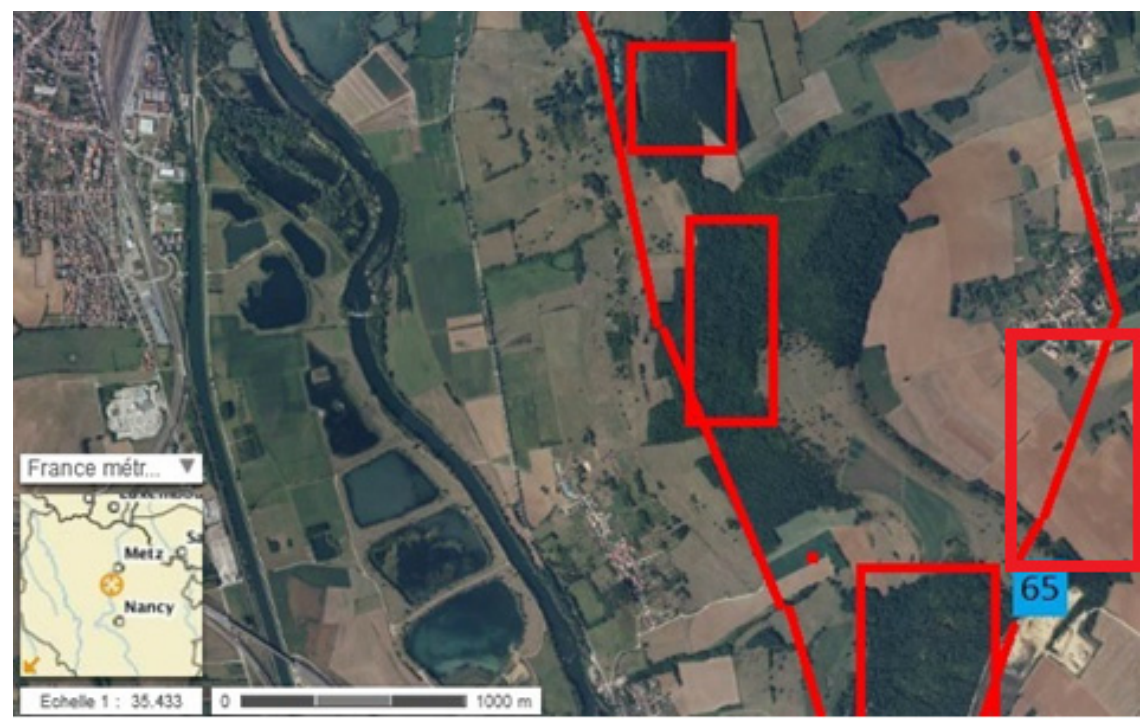

Figure 2: Froidmont and Arry plateaus aerial view (Cuesta of the Moselle, east bank). (Source: Geoportail; realisation: M.-M. Damien; location: blockhouses zones.) 


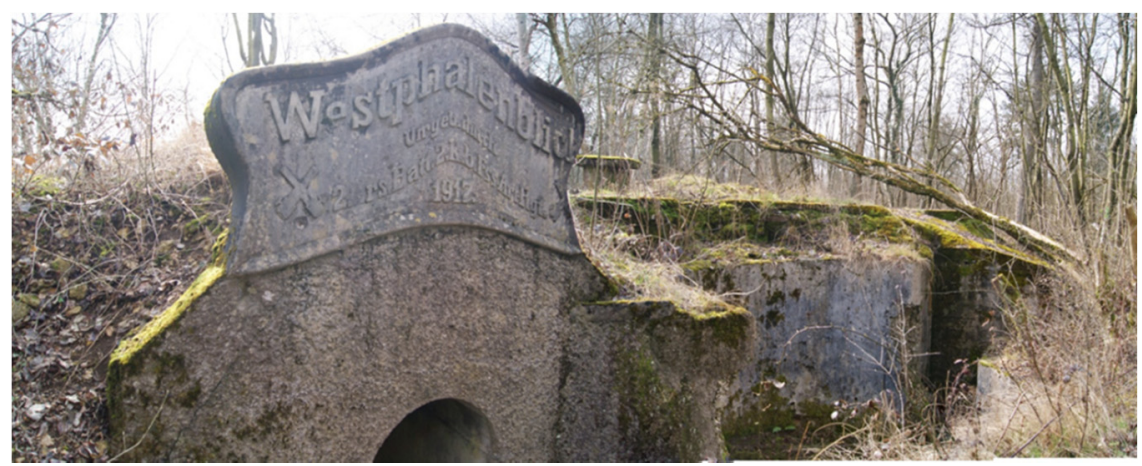

Figure 3: A decorated blockhouse (1916) Froidmont upland. (Photo M.-M. Damien (2012).)

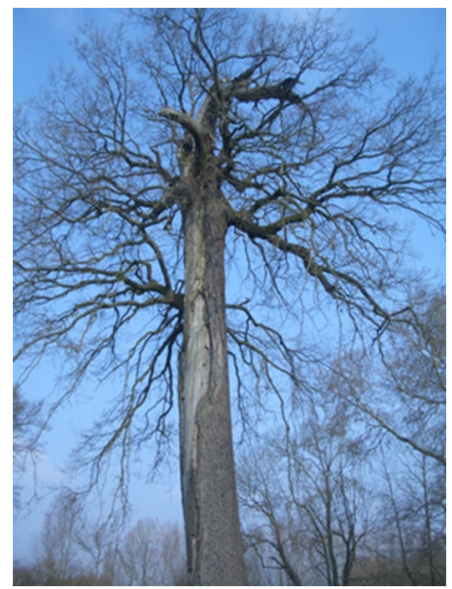

Figure 4: An observatory oak, Premesques (Nord) (M.-M. Damien 2013).

technology Lidar in the future as they are explored for Roman occupation now, episode indicated on the sites, but this about the first war is forgotten excepted in Alsace (Carspach). In the aerial-photography (fig. 1), the point 65 indicates the Pouget memorial and nearby the quarry. The fortifications are located inside the red rectangles. More than a hundred blockhouses are here illustrating the German position in the South of Metz (Froidmont Wood; Arry uplands (figs 1-3) identified with the inventory for the UNESCO project.

But, it is important to remain extremely vigilant in the case of particularly sensitive areas that must be protected, such as the conservation areas delimitated just after the end of the conflict about battlefields such as the Linge (the German 

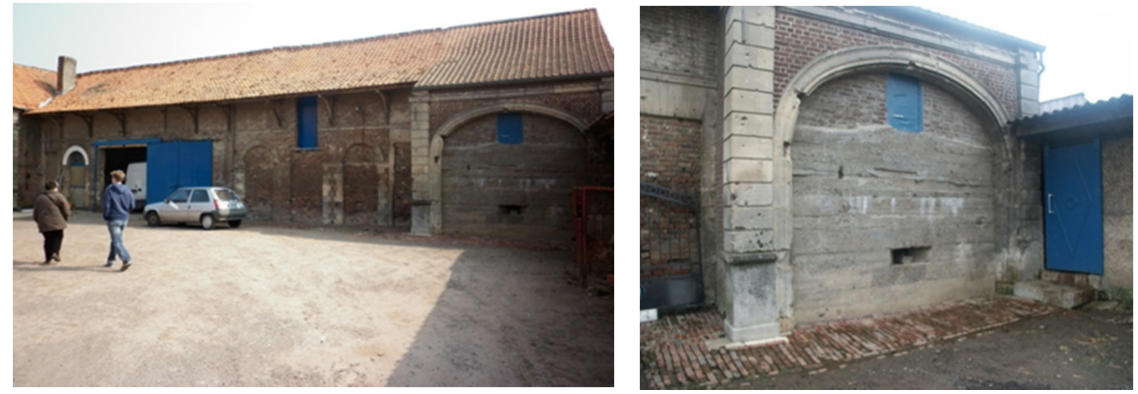

Figure 5: Hancardry Farm: a strong point (Ennetières-en-Weppes) (M.-M. Damien 4/04/2013.)

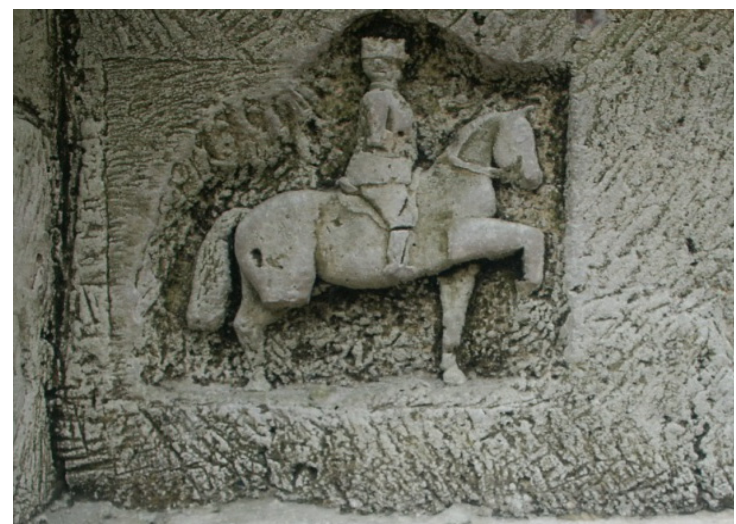

Figure 6: Sculpture Thiescourt, Chauffours quarry (Oise) (M.-M. Damien 2013).

Bärensthall cemetery is included in the perimeter but the French Wettstein Cemetery is not included); So, the Hartmannswillerskopf (1921/02/02: classified $\mathrm{MH})$ and "La Tête des Faux", Verdun Battlefield have been protected as Historic Monuments after the First World War. But, sometimes the conservation areas' perimeters may be revisited and reduced as for the Hartmannswillerskopf on the 16 March 1961.

We hope that the bill on Cultural heritage proposed by the government integrates the three UNESCO Conventions and is going to simplify the model rules of procedures by creating the "historic city", "the historic village ". So, many buffer zones surrounding World heritage properties on the List of World Heritage could belong to these types of conservation areas. 
Through the years 2014-2018, these sites will host many events, but after the great wave of public remembrance, these places risk to be forgotten. In France, only some archaeologists are interested by this thematic like Mr Defosses and M. Landolt. But this research must be more important to a better understanding of this terrible crisis. This heritage must be preserved to retain it in its integrity. The West Front may be the largest archaeological field in Europe to-morrow.

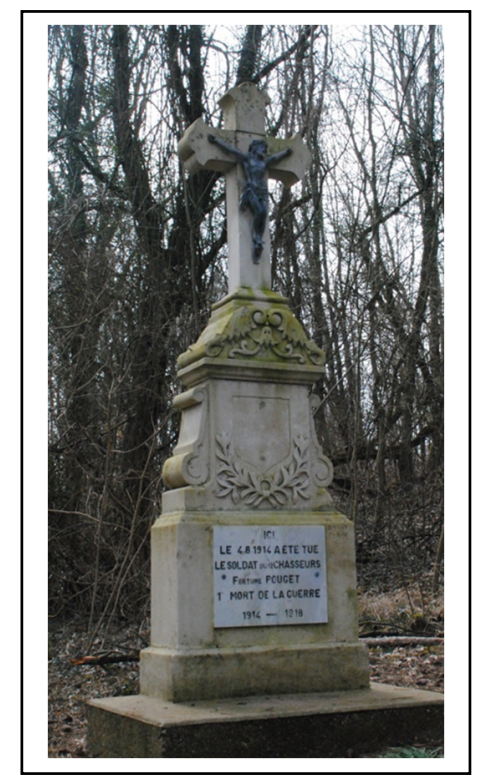

Figure 7: Pouget memorial Calvary (Froidmont upland) (M.-M. Damien 2013).

\subsection{The UNESCO project: the most important centenary project to make people and the authorities aware of this heritage for a better future}

This UNESCO project is a good project to make people aware of this heritage after the $100^{\text {th }}$ anniversary, especially the local communities, the young public but also sometimes the authorities through the land to the significance of this period of our world's history? How can this heritage be re-discovered by every one? What solutions can be found to preserve it? What legacy measures will be chosen? What partnerships will be developed to retain its integrity? How can the tourism help us to pass it to future generations?

These heritage places are valuable, scarce and important to the national and international community. They include landscapes. A variety of places own a significant for their cultural, indigenous, historical, natural and social heritage values. These places are not only significant for their association with the First World War but also important to the broader. It is very important that we manage 
this heritage places responsibly and openly, demonstrating to the community that we are worthy of their trust in the contribution we make to ensure a positive legacy for futures generations. In fact, only, some cemeteries, necropolis, have been currently protected as historic monuments by circular n ${ }^{\circ}$ 2000/022 (31 May 2000). As the CGCT article L. 2223-5 but, as a general rule, cemeteries or necropolis have to be enclosed to land use plans (Planning Laws: R. 126-1). Nobody can build a house, dig a well unless than one hundred metres away from cemeteries. Like any historic structure, our cemeteries require maintenance to ensure their longterm integrity without forgetting their surroundings as some other reminders of the Great War such as fortifications or hospitals...rarely protected.

\section{A removal strategy and master planning}

A great number of sites are a matter for The French" Pôle des Sépultures de Guerre et des Hauts Lieux de Mémoire"; the Commonwealth War Graves Commission (CWGC), the Volksbund Deutsche Kriegsgräberfürsorge (VDK), the American Battle Monuments Commission (ABMC), The South Africa Union, Romania, ... and every nation who lost people during the war will be associated to realize this objective. But they will be keeping their prerogatives over their own cemeteries. After the war, they got agreements for them: Agreement between the Governments of the United Kingdom of Great Britain and Northern Ireland, Portugal, United States, Canada, Australia, New Zealand, the Union of South Africa, India and Pakistan, Romania,... of the one part and the French Republic of the other part for instance. Germany was an exception, an agreement was signed later: French-German convention (19 July 1966). It is widely recognized that these structures invest heavily in managing and experiencing their traditions, culture, museums as memorabilia. Their service museums and archives allow the communities to gain an insight into this rich history. This work meshes well with efforts being made to manage Defence's heritage places.

\subsection{How to manage this project in the future? What is the "Landscapes and Sites association", a partner with Belgium doing for the "Cemeteries, Necropolis and Mausoleums UNESCO project?}

Managing the other public/private properties and coaching together with partners CWGC, VDK, PSGHM "Pôle des Sépultures de Guerre et des Hauts Lieux de Mémoire"...) and leading international relations with ICOMOS International, UICN and ICROM, with other States is implicating to imagine a strengthen structure [5]. So the French association "Landscapes and sites of the Great War" and the Flemish and Walloon governments have to form:

\subsubsection{Either a transnational association}

A gentle and easy way is a transnational association with the Flemish and Walloon governments: this structure is an elementary and simple solution but it is not the best international world famous company statute for ICOMOS international and other UNESCO-ONG; 


\subsubsection{Or a GECT: European Cultural Cooperation Group}

A GECT (European Cultural Cooperation Group) can manage these forgotten properties assessed and identified by this transnational co-ordination manager authority. This well-known grouping type has been created by Europe and supposes a financial engagement from every State (France and Belgium and others nations which would join it) and every General Council. GECT is a very serious structure for UNESCO and ICOMOS and a true engagement for managing, protecting all the properties to retain; raising public awareness of people. GECT is the ideal structure for asking European subsides through Interreg V, VI, Leader for managing common actions (international website, international communication and marketing, international scientific programs about historic or archaeological research, and properties maintenance) with agreement and consultation with the local Belgian and French communities, the departmental managers and other relevant stakeholders as required Associations.

But also, these actions can be taken with every generation, department by department. They could be inter-departmental projects driven by an interdepartmental center of excellence such as Haut-Rhin/Vosges/Meurthe and Moselle; this center-type is what is happening today. So European subsides may be obtained by these local structures, the leader program is the best for the rural lands.

GECT would be an ideal authority to plan to assess our well-known heritage places in preparation for a possible nomination for inclusion on the national heritage list. How to preserve some new sites?

\subsection{A toolkit for the First World War Heritage}

The UNESCO First World War toolkit (Defence government.au $[5,6]$ ) will be designed to assist local authorities, associations and anyone in understanding places and managing things of heritage value within the transnational project. It provides practical guidance on how to progress development proposals, methods for managing heritage and where to go for further information in particular contexts.

The toolkit is practical. The toolkit is for use by all association members as we all have a stake in our heritage and we all have a hand in managing heritage value.

\subsection{To an important investment in this heritage}

It is very important for the association and for the inscription project to manage and invest in this heritage:

- It contributes to valuing and preserving the remembrance of these important human losses;

- It enhances and provides context to the people visiting or living environment: interpretation zones will be created to explain the cemeteries and their being: example for Fromelles battle or Sarrebourg;

- It improves the association's public image and bridges to the General Councils and the local communities (municipalities, associations); 
- It must play an important role in Association capability through its contribution to morale, recruitment and retention outcomes;

- The Flemish and Walloon governments, the French association 'Landscapes and Sites of Remembrance, represent the people, land and values that they defend. The cemeteries, monuments, sites, memorabilia precincts and stories that make up our environment are living and strong connections to the contributions of "those who have gone before";

- The First World War history is intrinsically bound up with our identity as nations. The historic places our guardianship some part of the world values that we have made a commitment to protect and defend;

- By using this toolkit anybody will be ensuring that they are managing the heritage values of the cemeteries, memorials or monuments and other things or sites of the First World War and meeting their legal obligations.

\subsection{Tools to assist an inventory and a management for a site}

Many tools can assist everybody to identify, assess and manage site's heritage values and planning issues such as:

- Heritage Great War web site: This site is the association "Landscapes and sites of the Great War's website; it can become GECT's website. This site contains the list off all identified properties and thus is a quick and easy reference tool to check a site.

- Association or GECT management system: Association or GECT is working with Estates management systems. Its site contains the list of all the partners (CWGC, VDK, ABMC, South African Union) and indicate connexions with the Ministries' databases (Merimée). It contains listings through the occidental Front. Connexions with Ministries, National Archives and Libraries bases, or specialised bases such as DMPA or ECPAD or international databases such as Canadian, Australian bases...[5, 6 Defence government] provide further information about heritage sites. Sometimes it is possible to get a copy of the latest Heritage Management Plan of sites to help you to imagine your project.

- Ministry of Culture and Ministry of the Environment's website: for France, for example, you can get information on some sites if they have protection areas with Merimée basis (Ministry of Culture) or Carmen basis (DREAL, Environment and Housing Ministry). These lists contain further information about the site's values.

We must perfect our management system and our tools; we are working on them (see Table 1). 
Table 1: $\quad$ Strategic and master planning checklist.

\begin{tabular}{|c|c|}
\hline & Find the answer \\
\hline $\begin{array}{l}\text { 1-Find out if the site is on the } \\
\text { Commonwealth Heritage List, } \\
\text { the VDK list," The pole des } \\
\text { Sépultures de guerre et des } \\
\text { Hauts Lieux de Mémoire", the } \\
\text { French DREAL or DRAC lists, } \\
\text { the register of another country }\end{array}$ & $\begin{array}{l}\text { Check the "Memory Landscapes and Sites } \\
\text { register" } \\
\text { www.heritage-grande guerre } \\
\text { Check the CWGC database: } \\
\text { www cgwc.org; the Canadian database } \\
\text { Check the French Heritage database: } \\
\text { www culture.gouv.fr (Merimee or Palissy } \\
\text { database) }\end{array}$ \\
\hline $\begin{array}{l}\text { 2-Find out if the site is not listed } \\
\text { but has identified with a } \\
\text { potential value }\end{array}$ & $\begin{array}{l}\text { Check with the Dreal or Drac region's Senior } \\
\text { Managers } \\
\text { Check the regional register }\end{array}$ \\
\hline $\begin{array}{l}\text { 3-Find out more about the } \\
\text { nature of the heritage values } \\
\text { including cultural, natural, } \\
\text { indigenous historic values }\end{array}$ & $\begin{array}{l}\text { See if there is a conservation management plan } \\
\text { or heritage assessment for the place } \\
\text { Check that list is up to date } \\
\text { These plans are available in the French } \\
\text { Environment System or DRAC Monument } \\
\text { System }\end{array}$ \\
\hline $\begin{array}{l}\text { 4-If the site or monument is not } \\
\text { listed but has a heritage value } \\
\text { including cultural, natural, } \\
\text { indigenous, historic values }\end{array}$ & $\begin{array}{l}\text { Contact the "Memory landscapes and sites } \\
\text { Association" } \\
\text { Contact local historical associations } \\
\text { Contact the local authority of the community } \\
\text { If you use the "Paysages et sites de mémoire" } \\
\text { Panel who will provide advice through the } \\
\text { First World War Military Heritage Panel } \\
\text { Advisory Service and if it is an exceptional site } \\
\text { will contact the Ministry of Culture. } \\
\text { In some cases you will need to develop a } \\
\text { heritage impact assessment for proposals that } \\
\text { may affect heritage values; the association will } \\
\text { give you a standard statement of requirement } \\
\text { cf. Guide under "standard management plans" }\end{array}$ \\
\hline 5-Get advice & $\begin{array}{l}\text { Check with "Memory Landscapes and Sites } \\
\text { Association" or GECT, if you need further } \\
\text { advice } \\
\text { If so, you can use The Ministry of Culture by } \\
\text { DRAC or Preventive Archaeology Local } \\
\text { Advisory Service }\end{array}$ \\
\hline
\end{tabular}




\section{Conclusion}

The UNESCO project is a good one because it is about mobilizing local communities, local associations and the great public actors to inform choicemaking processes for the sites to propose. A large inventory along the French front has been realized or is being realized. For instance, more three hundred elements of the historic heritage have already inventoried in the Moselle Department, in the Ardennes Department, six hundred in the North Department, without the cemeteries, necropolis, memorials (i.e. 80 in Moselle; more 350 in Pas-deCalais...). Through networking, it is raising public awareness, including youth public and farmers, of this intercultural historic heritage. It is very important. This project belongs to the local associations and communities. This heritage transmission depends of them and of their investment in the future no State can alone leave this legacy for future generations.

\section{References}

[1] Archives of the all the West French Front departments: North, Pas-de-Calais, Ardennes, Somme, Oise, Aisne, Moselle, Marne, Meuse, Meurthe and Moselle, Vosges, Haut-Rhin, Bas-Rhin, Belfort territory, Seine and Marne.

[2] Chatenet M, Verdier H. Davoigneau J., Benoit-Cattin R., de Massary X., Gauthiez B, Manigand-Chaplain C., Thesaurus of the French Architecture, edited by the French Ministry of Culture and Communication, 187 pages, 2000.

[3] Architecture Dictionary edited by the French Ministry of Culture and Communication online, Edition 18/12/2013.

[4] The Heritage of the Great War /First World War 14-18 www.greatwar.nl/.

[5] Defence Environmental Management - Heritage Management www.defence.gov.au/environment/heritage.HTM.

[6] Heritage Toolkit - Department of Defence www.defence.gov.au /environment/heritagetoolkit.pdf. 